\title{
JPEB
}

Jurnal Penelitian Ekonomi dan Bisnis, 1 (2), 2016, Hal: 86 - 99

\section{ANALISIS PENGALAMAN PETANI ORGANIK: EKSPLORASI PENGALAMAN PETANI ORGANIK DENGAN INTERPRETATIVE PHENOMENOLOGICAL ANALYSIS}

\author{
Muhammad Rifai Rais ${ }^{1}$, Darwanto ${ }^{2}$ \\ Fakultas Ekonomika dan Bisnis,Universitas Diponegoro \\ Jalan Prof. Soedarto SH Tembalang, Semarang \\ *Corresponding Author : rifai1923@gmail.com
}

Diterima : Februari 2016; Direvisi : Juni 2016; Dipublikasi : September 2016

\begin{abstract}
The organic farming system is an agricultural system that keeps the environment-friendly. The organic farming system is expected to be a solution for building agriculture and improving the welfare of farmers. This study aims to explore and understand the experience gained by individuals in living organic farming systems. The study used the Interpretative Phenomenological Analysis (IPA) approach that aims thedepth of meaning against various backgrounds, experiences, unique events, and subject thinking through indepth interviews. The results found that the organic farming systemapplicationled to a variety of the organic farming system experience.Organic farming systems that have been implemented at the moment are still constrained so that social capital in the form of values, norms, trusts and social networks play a role in overcoming these obstacles. Development of organic agriculture is expected to encourage economic aspects, health aspects, and ecological aspects.
\end{abstract}

Keywords: Organic Farming; Experience; Social Capital; Phenomenological

\section{ABSTRAK}

Sistem pertanian organik merupakan sistem pertanian yang menjaga aspek ramah lingkungan. Sistem pertanian organik diharapkan menjadi solusi dalam membangun pertanian dan meningkatkan kesejahteraan petani. Penelitian ini bertujuan untuk mengeksplorasi dan memahami pengalaman yang diperoleh individu dalam menjalani sistem pertanian organik. Penelitian menggunakan pendekatan Interpretative Phenomenological Analysis (IPA)dengan tujuan memperoleh kedalaman makna terhadap berbagai latar belakang, pengalaman, peristiwa unik, dan pemikiran subjek melalui wawancara mendalam. Hasil penelitian ini menemukan bahwa penerapan sistem pertanian organik memunculkan berbagai macam pengalaman sistem pertanian organik. Sistem pertanian organik yang telah diterapkan hingga saat masih mengalami kendala sehingga modal sosial berupa nilai, norma, kepercayaan dan jaringan sosial berperan dalam mengatasi kendala tersebut. Pembangunan pertanian organik diharapkan mendorong aspek ekonomi, aspek kesehatan, dan aspek ekologi.

Kata Kunci : Pertanian Organik; Pengalaman; Modal Sosial; Fenomenologi 


\section{PENDAHULUAN}

Indonesia merupakan negara agraris dengan hasil pertanian, kehutanan, perkebunan, maupun hasil laut yang melimpah. Kondisi tersebut menjadikan peluang bidang pertanian terbuka bagi sebagian besar masyarakat lokal. Pertanian merupakan kegiatan pemanfaatan sumber daya hayati dengan tujuan menghasilkan bahan pangan, bahan baku industri, atau sumber energi, serta untuk mengelola lingkungan hidupnya. Kegiatan tersebut umumnya disebut sebagai budidaya tanaman atau bercocok tanam. Banyak sedikitnya hasil pertanian bergantung pada kondisi alam dan cara mengolah pertanian itu sendiri. Oleh sebab itu, banyak upaya dilakukan untuk mengolah pertanian guna memaksimalkan hasil pertanian sebagai sumber pangan dan pendapatan bagi para petani. Hal ini juga sebagai sarana untuk membangun ekonomi guna memaksimalkan potensi setiap daerah masing-masing.

Provinsi Jawa Tengahmerupakan salah satu provinsi di Pulau Jawa yang wilayahnya berlokasi diantara Provinsi Jawa Barat dan Provinsi Jawa Timur. ProvinsiJawa Tengah terbagi atas 29 kabupaten dan 6 kota. Luas wilayah Provinsi Jawa Tengah mencapai 3,25 juta hektar (25,04 persen dari luas Pulau Jawa). Wilayah Provinsi Jawa Tengah adalah lahan sawah dan lahan bukan sawah. Sebagian besar lahan di Provinsi Jawa Tengah adalah lahan bukan sawah dengan luas hingga 2, 25 hektar (69,20 persen luas wilayah Provinsi Jawa Tengah). Penggunaan lahan meliputi : 1) lahan sawah berpengairan teknis (38,26 persen); 2) lahan berpengarian setengah teknik; 3) lahan tadah hujan; serta lainnya. Potensi lahan sawah Provinsi Jawa Tengah mampu untuk ditanami padi hingga mencapai 69,59 persen.

Polusi tanah merupakan salah satu permasalahan terjadi di Indonesia. Penggunaanbahan-bahan kimia seperti pupuk dan pestisida akan mengakibatkan tanah dan air tanah tercemar oleh zat kimia.Seiring adanya pengendapan pestisida maupun bahan agrokimia lain dalam waktu lama menyebabkan degredasi tanah pertanian. Sehingga upaya pengembalian nutrisi tanah memerlukan waktu hingga ratusan tahun. Degredasi tanah pertanian mengakibatkan produktivitas yang menurun dikarenakan hilangnya kemampuan tanah untuk memproduksi nutrisi. Data BPS Provinsi Jawa Tengahmenunjukkan adanya penurunan hasil pertanian pada tahun 2014. Hasil pertanian tahun 2010 mencapai 10.110 .830 ton, sedangkan tahun 2014 hanya 9.648.10 ton. Pengembangan pertanian berbasis organik diharapkan dapatmenjaga kondisi tanah dari kerusakan agar hasil pertanian tetap stabil. Data BPS pada tahun 2014 Jawa Tengahmenunjukan bahwa angka tertinggi kasus kerusakan tanah terjadi pada 183 desa dengan kondisi tanah yang tercemar.

Pertanian organik di Indonesia mengalami peningkatan seiring berjalannya tahun.Peningkatan tersebut sesuai dengan hasil penelitian yang telah dilakukan FiBL, IFOAM, serta AOI (Aliansi Organik Indonesia). Peningkatan pertanian organik di Indonesia ditunjukkan oleh meningkatnya luas area pertanian organik, yaitu dari 40.970 Ha pada tahun 2007 menjadi 225.062 Ha pada tahun 2011.

Pertanian organik membutuhkan lahan yang terbebas dari cemaran bahan kimia dan mudah untuk dijangkau (aksesbilitas baik). Pemilihan lahan mempertimbangkan kualitas dan luas lahan peruntukan pertanian organik. Lahan yang belum tercemarmerupakan lahan yang belum diusahakan, tetapi secara umum lahan demikian kurang subur. Lahan yang subur umumnya telah diusahakan secara intensif dengan menggunakan bahan pupuk dan pestisida kimia. Konversi lahan tercemar bahan kimia tersebut membutuhkan masa konversi hingga mencapai dua tahun. Provinsi Jawa Tengah sudah mulai mengembangkan upaya konversi lahan tercemar dibeberapa tempat salah satunya di Kabupaten Sukoharjo.

Fenomena sistem pertanian organik di Kabupaten Sukoharjo dimulai oleh seorang petani yang bernama Setyarman. Setyarman memulai sistem pertanian organik dimulai dari tahun 1999 ketika itu beliau mengikuti SLPTH (Sekolah Lapangan Pengendalian Hama Terpadu) yang diadakan oleh Kementerian Pertanian. Setyarman mempelajari sistem pertanian organik dari keikutsertaanya pada SLPTH. 
Pengembangan sistem pertanian organik dianggap sangat perlu dilakukan. Saat ini masyarakat memiliki kesadaran akan pentingnya konsumsi makanan sehat tanpa zat kimia. Pola hidup sehatsudah diterapkan secara internasional sehingga peraturan keamanan dan kualitas pangan internasionalharus dipenuhi oleh produk-produk pangan. Jaminan produk pertanian harus beratribut aman dikonsumsi (food safety attributes), kandungan nutrisi tinggi (nutritional attributes) dan ramah lingkungan (eco-labelling attributes). Penerapan metode pertanian organik merupakan salah satu upaya yang dapat dilakukan untuk memperoleh pangan yang sehat dan bergizi (Yanti, 2005). Maka dari itu guna menopang permintaan yang terus menerus bertambah maka sistem pertanian organik di Kabupaten Sukoharjo ini sangat layak untuk dikembangkan.

Kabupaten Sukoharjo dengan potensi alam yang mendukung untuk pengembangan pertanian dan kultur masyarakat yang sebagian mengandalkan penghasilannya dari hasil olahan pertanian maka Kabupaten Sukoharjo sangat perlu untuk mengembangkan sistem klaster organik. Pertanian organik nantinya diharapkan mampu meningkatkan hasil pertanian dan juga meningkatkan kesejahteraan petani. Dibeberapa daerah pertanian organik mampu meningkatkan kesejahteraan petani seperti hasil penelitian Mayrowani et al (2010) didapatkan hasil bahwa pertanian organik dampak mendongkrak pendapatan petani 20-30 persen.

Beberapa permasalahan dalam sistem pertanian organik yang diterapkan oleh kelompok tani JARPETO adalah beberapa petani masih belum lepas secara total dari penggunaan pupuk kimia. Beberapa petani sengaja mencampur pupuk organik dengan pupuk kimia. Menurut Setyarman petani beralasan bahwa penggunaan pupuk kimia memiliki masa panen lebih cepat dan juga hasil pertanian yang lebih hijau. Sedangkan menurut Sumaryono alasan dia enggan berpindah total ke sistem pertanian organik karena menurut dia perpindahan dari kimia ke organik dibutuhkan penyesuaian lahan sekitar tiga musim atau tiga kali masa panen. Hal tersebut sejalan dengan penelitian Widiarta (2011) menurut Widiarta dalam penelitianya kelemahan penggunaan pupuk organik adalah pertumbuhan tanaman agak lambat hasil pertanian dari penggunaan pupuk kimia lebih tahan hama dan produksi berkualitas tinggi. Sedangkan menurut Roidah (2013) pertanian organik membutuhkan waktu untuk mencapai hasil maksimal. Alokasi waktu dibutuhkan untuk tahapan konservasi tanah sehingga diperoleh keseimbangan tanah dan hasil pertanian organik jauh lebih baik daripada penggunan pupuk kimia.

Masalah lain yang dihadapi petani yaitu tentang asumsi yang berkembang dikalangan petani konvensional bahwa sistem pertanian organik merupakan sistem yang terlalu sulit untuk dikerjakan. Penelitian ini berusaha mengeksplorasi pengalaman dari petani yang telah konsisten menerapkan sistem pertanian organik guna menjawab keraguan tentang sistem pertanian organik dikalangan petani yang belum berpindah ke sistem pertanian organik.

\section{LANDASAN TEORI \\ Pertanian Organik}

Pertanian organik berdasarkan pengertian sistem standarisasi Indonesia (SNI 01-67922002) dijelaskan sebagai suatu manajemen produksi yang diterapkan pada pertanian yang memiliki dampak positif terhadap kesehatan konsumen dan agroekosistem. Kesehatan agrosistem mencakup keragaman hayati, siklus biologi, dan aktivitas biologi tanah. Pembangunan pertanian dijelaskan Mosher dalam Hadisapoetro (1975)sebagai bagian integral pembangunan ekonomi dan masyarakat secara umum. Pembangunan pertanian memberikan dampak positif terhadap kesejahteraan masyarakat khususnnya masyarakat yang bermata pencaharian sebagai petani dan menggantungkan kehidupannya kepada sektor pertanian.

Pertanian organik modern di Indonesia melalui pengembangan usahatani sayuran di Bogor, Jawa Barat oleh Yayasan Bina Sarana Bakti (BSB) di tahun 1984 (Prawoto and Surono, 2005; Sutanto 2002). Pertumbuhan luas pertanian organik dari tahun 2008 hingga 
2009 tidak terlalu signifikan, hanya 3 persen. Luas area pertanian organik Indonesia tahun 2010 adalah 238,872.24 ha, meningkat 10 persen dari tahun sebelumnya (2009). Namun pada tahun 2011 menurun 5,77 persen dari tahun sebelumnya menjadi 225.062,65 ha. Penurunan terjadi karena menurunnya luas areal pertanian organik tersertifikasi sebanyak 13 persen.Hal ini disebabkan karena jumlah pelaku (petani madu hutan) tidak lagi melanjutkan sertifikasi produknya tahun 2011. Semakin luasnya pertanian organik, diharapkan bisa memberikan manfaat yang lebih luas dalam pemenuhan permintaan masyarakat akan pangan yang sehat dan berkelanjutan. Pertanian organik saat ini telah berkembang secara luas, baik dari sisi budidaya, sarana produksi, jenis produk, pemasaran, pengetahuan konsumen dan organisasi atau lembaga masyarakat yang menaruh minat (concern) pada pertanian organik.

\section{Ekonomi Kelembagaan}

Ekonomi kelembagaan merupakan ilmu yang mempelajari mengenai peranan kelembagaan dalam suatu sistem dan organisasi ekonomi/sistem terkait yang meliputi property right atau hak pemilikan. Property rightterdapat pada bentuk aturan formal, norma sosial dan adat. Kaitan hak kepemilikan ini tergantung pada besarnya upaya pelaksanaan dan pengakuan masyarakat.

Modal sosial dijelaskanPutnam (1996) sebagai bentuk corak kehidupan sosial jaringan, norma, dan kepercayaan yang menjadikan para pelaku terkait (participant) bersama bertindak lebih efektif dalam pencapaian tujuan bersama. Modal sosial ditanamkan dan dikembangkan dengan adanya pengaruh dari norma moral suatu komunitas dan kebajikan seperti kejujuran, kesetiaan, dan kemandirian (Fukuyama, 2001).

\section{METODE PENELITIAN}

Penelitian ini menggunakan model fenomenologi dengan pendekatan kualitatif. Penggunaan model ditujukan untuk memahami peristiwa-peristiwa yang terjadi sebagai dampak adanya interaksi pihak terkait. Pihak-pihak terkait tersebut mempunyai pemahaman atau interpretasi pada setiap peristiwa sehingga tindakan selanjutnya dapat ditentukan. Penggunaan fenomenologi didasarkan pada informasi yang berasal dari pengalaman yang disadari responden terkait penelitian.

Penelitian dilakukan di Kabupaten Sukoharjo. Subjek penelitian adalah kelompok tani JARPETO di Kabupaten Sukoharjo. Pertanian merupakan sektor unggulan yang ada di Kabupaten Sukoharjo dan penting dalam pertumbuhan ekonomi. Pertanian organik dipilih karena diharapkan mampu mengembangkan gairah ekonomi petani dan mampu memperluas lapangan kerja. Pengembangan model pertanian organik nantinya diharapkan mampu menjadi unggulan dan memberikan dampak sosial yang positif.

Penentuan sampel dalam penelitian menggunakan teknik purposive sampling. Herdiansyah (2009) menjelaskan bahwa teknik purposive sampling merupakan teknik pemilihan subjek dan lokasi penelitian yang bertujuan untuk mempelajari/memahami permasakahan pokok yang diteliti.Sampel pada penelitian ini disebut sebagai subjek/informan penelitian. Informan/subjek penelitian adalah petani organik yang tergabung dalam organisasi JARPETO Kabupaten Sukoharjo.

Penelitian Interpretative Phenomenological Analysis dalam praktek penelitiannya menerapkan jumlah informan/subjek sebanyak minimal tiga orang sebagai ukuran standar bagi studi sarjana dan master(Smith, Flowers, \& Larkin, 2009).Informan/subjek penelitian ditentukan berdasarkan sampel teoritis yang sesuai dengan tujuan penelitian dan pengalaman yang dimiliki informan selama menjalani sistem pertanian organik. Beberapa kriteria informan di antaranya sebagai berikut:

1. Petani yang aktif dalam anggota JARPETO 
2. Telah menerapkan sistem pertanian organik dalam waktu lama (minimal lebih dari dua kali masa panen)

3. Memiliki informasi mendalam terkait dengan penelitian

4. Berdomisili di wilayah Kabupaten Sukoharjo.

5. Bersedia menjadi Informan/subjek

Metode Interpretative Phenomenological Analysis (IPA) merupakan metode yang digunakan untuk menganalisis data penelitian. Metode Interpretative Phenomenological Analysis merupakan metode analisa yang dikembangkan oleh Jonathan A.Smith dan Mike Osborn yang didasarkan pada fenomenologi, ideografis, hermeneutika dan interaksi simbolis. Dalam kasus IPA, fokus perhatian analisis secara langsung mengarah kepada usaha subjek untuk memperoleh makna dari pengalamannya (Smith, Flowers, \& Larkin, 2009).

Data penelitian diperoleh melalui observasi dan wawancara, khususnya wawancara mendalam (in-depth interview). In-depthinterview pada penelitian fenomenologi memiliki pengertian sebagai bentuk upaya untuk memperoleh informasi mengenai objek penelitian secara mendalam dan mendetail dengan tujuan diperolehnya pemahaman objek penelitian (fenomena sosial dan pendidikan). Data yang diperoleh kemudian dianilisis dengan metode Interpretative Phenomenological Analysis.

Penelitian fenomenologi memiliki beberapa langkah dalam analisis data yaitu (Smith, Flowers, \& Larkin, 2009):

1. Langkah 1 : Membaca dan membaca ulang

Langkah pertama dalam sebuah analisis IPA melibatkan seseorang lebih dalam pada beberapa data original.

2. Langkah 2: Pencatatan awal

Tahapan analisis awal merupakan tahapan yang paling rinci dan menghabiskan waktu. Langkah ini memeriksa konten semantik (pembelajaran makna dan bahasa) digunakan pada tingkat eksplorasi lebih. Analis mempertahankan sebuah pemikiran terbuka dan catatan apapun tentang perhatian dalam transkip

3. Langkah 3: PengembanganEmergent Themes

Tema yang muncul ditemukan oleh peneliti berdasarkan transkrip dan komentar eksploratif yang telah dibuat sebelumnya.

4. Langkah 4: Pengembangan Tema Super-ordinat

Tema super-ordinat merupakan kumpulan temadalam satu konteks. Tema super-ordinat yang telah ditentukan lebih baik tidak lepas dari cakupan pertanyaan penelitian secara umum.

5. Langkah 5 : Mendeskripsikan tema

Tahap mendeskrisipkan tema ini merupakan tahap terakhir yang dilakukan peneliti untuk melakukan interpretasi hasil wawancara.

\section{HASIL DAN PEMBAHASAN}

Analisis Interpretative Phenomenological Analysis (IPA)

Analisis Interpretative Phenomenological Analysis (IPA) yang telah dilakukan sesuai dengan tahapan dalam penelitian fenomenologi menghasilkan beberapa tema yang telah ditentukan berdasarkan hasil dari pengembangan tema super-ordinat yang ditunjukan pada Tabel 1. 
Tabel 1. Tema Super-ordinat

\begin{aligned} & \hline \multicolumn{1}{c}{ Tema Super-ordinat } \\ & \hline - Memberikan pandangan dan pengalaman dalam bertani. \\ & - Efek psikologi dari bertani organik. \\ &- Efek positif terhadap kesehatan. \\ &- Bertani organik karena faktor religius. \\ &- Efek positif terhadap kondisi ekonomi. \\ & - Bertani organik memberi efek positif terhadap kondisi pertanian. \\ & \hline\end{aligned}

Tema Super-ordinat yang ditunjukan oleh Tabel 1. disusun berdasarkan pengelompokan dari tema-emergent themes yang muncul dari setiap subjek yang kemudian dideskripsikan. Hasil deskripsi tema tersebut yaitu :

\section{Pandangan dan Pengalaman Baru Bertani.}

Pembangunan pertanian organik di Indonesia telah dilakukan sejak masa penjajahan Belanda, namun saat itu masyarakat masih belum menyadari dampak positif (Oudejans, 2006). Hal tersebut menunjukan bahwa pertanian organik merupakan kebudayaan lokal petani di Indonesia pada saat itu. Pendapat Oudejans tersebut sesuai dengan pengalaman Setyarman dan Rubadi, kedua subjek mengartikan pertanian organik sebagai sistem pertanian yang sudah diterapkan oleh orang tua mereka. Mereka berpendapat bahwa mereka sebenarnya telah mempraktikan pertanian organik sejak kecil, pada waktu mereka kecil mereka diajari bagaimana cara membuat pupuk menggunakan kotoran hewan membuat pembasmi hama menggunakan air kencing manusia. Namun pada waktu itu mereka belum mengenal istilah pertanian organik dan manfaat yang didapat dari bertani organik.

Sejak masuknya era pertanian modern sistem pertanian organik mulai ditinggalkan masyarakat indonesia, mereka memilih berganti ke sistem pertanian modern yang menggunakan bahan-bahan kimia sebagai bahan baku pengolahannya. Sejak saat itu pertanian organik sangat awam dikalangan para petani, sebagian petani menganggap bahwa pertanian organik merupakan sistem pertanian yang sulit untuk dilakukan. Widiarta (2011) berpendapat bahwa alasan yang menyebabkan petani tidak banyak mengadopsi pertanian organik adalah; pola pikir petani yang pragmatis dan sudah terbiasa dengan pertanian konvensional sebagai dampak revolusi hijau. Sedangkan menurut Suwantoro (2008), salah satu kendala pengembangan pertanian organik adalah adanya kebiasaan para petani konvesional dalam penggunaan bahan kimia (pemupukan dan pencegahan hama) dalam usaha pertanian untuk mencapai hasil yang baik.

Hal ini sejalan dengan pendapat Setyarman, Kasno, Sugiyo dan Rubadi, menurut Setyarman pendapat bahwa pertanian organik susah untuk dilakukan hanyalah asumsi-asumsi yang ada dikalangan petani yang sebenarnya petani yang membuat asumsi tersebut belum melakukan sistem pertanian organik. Setyarman menambahkan bahwa dia pada saat bertani organik tidak mengalami kesulitan karena bahan baku dalam bertani organik ada disekitarnya. Sugiyo berpendapat bahwa pendapat bertani organik itu rumit tidak dia rasakan pada saat bertani organik dan berjalan dengan baik. Kasno berpendapat bahwa petani tidak mau "rebyek" (repot) padahal petani tau ilmu ilmu bertani organik tetapi tidak mau melakukannya karena mereka enggan untuk berpindah. Sedangkan Rubadi berpendapat bahwa mindset petani tentang cara bertani itu sulit untuk dirubah, menurut Rubadi merubah petani untuk diajak bertani organik itu harus pelan-pelan karena menurutnya mengubah petani untuk bertani organik itu sangat sulit. 
Bertani organik membawa pengalaman baru para petani, mereka mengalami dampak dari proses perpindahan dari bertani kimia ke organik. Sugiyo menceritakan pengalamannya dalam berpindah dari kimia ke organik bahwa dirinya berpindah secara bertahap yaitu dengan semi organik setelah berjalan beberapa tahun baru meninggalkan bahan kimia secara total, hal tersebut dikarenakan bahwa pada awal menggunakan sistem organik mengalami perubahan terhadap hasil panennya. Rubadi juga mengungkapkan hal yang sama bahwa pengalamannya pada saat tahun pertama menjalani sistem pertanian organik dia mengalami penurunan hasil, setelah tahun ketiga dia mulai merasakan keuntungan menerapkan sistem pertanian organik. Pendapat Sugiyo dan Rubadi tersebut sama dengan pendapat Suwantoro (2008) yaitu kondisi yang dinilai kritis dan berat bagi usaha pertanian organik adalah waktu tanam pertama hingga waktu tanam ketiga dikarenakan apabila budidaya organik diterapkan pada usaha pertanian sering berdampak negatif pada hasil produksi.

Berdasarkan pengalaman yang dijalani petani organik JARPETO, sebenarnya menerapkan sistem pertanian organik sama halnya dengan kembali ke masa lampau yaitu menerapkan sistem yang telah mereka jalani dulu sebelum era revolusi hijau dicanangkan pemerintah.

\section{Efek Psikologis dari Cara Bertani Organik}

Pertanian organik merupakan sistem yang masih belum dikenal oleh sebagian petani, munculnya sistem pertanian organik membawa efek secara psikologis bagi para petani organik. Efek psikologis yang ditimbulkan bersifat negatif dan positif, dari keempat subjek tiga diantaranya mengalami efek positif yang ditimbulkan karena sistem pertanian organik yang mereka jalani. Perubahan sistem pertanian yang diterapkan petani berdampak pada perubahan sosial yang mereka alami. Hubungan sosial masyarakat sebagai salah satu faktor dalam pelaksanaan sistem pertanian organik, hubungan sosial bisa menjadi penghambat dan pendorong berkembangnya sistem pertanian organik. Hal ini sejalan dengan Anonim (2011) yaitu adanya perubahan memberikan dampak positif maupun negatif terhadaptatanan masyarakat. Dampak positif dari perubahan sosial berupa meningkatnya taraf hidup masyarakat sedangkan dampak negatifnya munculnya konflik sosial yang timbul dari perubahan.

Setyarman mengalami dampak negatif dari perubahan yang dia jalani, Setyarman mengaku mendapat cibiran dari para petani karena apa yang dilakukan setyarman dalam bertani organik dianggap hal yang tidak wajar dikalangan petani lain. Tetapi hal tersebut tidak menyurutkan niat Setyarman untuk terus menerapkan sistem pertanian organik yang dianggap aneh oleh sebagian petani. Setyarman menambahkan bahwa anggapan-anggapan tersebut muncul karena asumsi-asumsi negatif tentang pertanian organik yang ada ditengah petani. Sedangkan Kasno merasakan kekecewaan yang ditimbulkan dari hubungan sosial yakni lahan yang dia kelola secara organik tercemari oleh petani yang memiliki lahan disampingnya yang secara sengaja menggunakan racun sebagai obat pengusir hama, secara tidak langsung partikel racun tersebut terbawa angin sampai ke lahan pertanian Kasno.

Dampak Psikologis lain yang ditimbulkan dengan munculnya pertanian organik adalah rasa senang yang dialami oleh petani organik. Kasno mengungkapkan rasa senang karena prestasi-prestasi yang didapatkan dari dia bertani organik, Kasno meneceritakan bahwa dengan bertani organik dia bukan hanya sekedar bertani tapi mampu membuat dirinya berprestasi yaitu dengan penghargaan yang dia terima, hal tersebut menjadi pelecut semangat bagi dirinya untuk terus bertani secara organik.. Sedangkan Rubadi merasakan dirinya sudah senang terhadap pertanian organik yang membuat dirinya tidak merasakan ragu dan malas dalam bertani organik. Minat yang timbul dari Kasno dan Rubadi yang merasakan bahwa dirinya sudah senang terhadap pertanian organik menjadi pelecut semangat keduanya untuk terus bertani organik bahkan mendapatkan prestasi demi prestasi dari pertanian organik itu sendiri. Hal tersebut sejalan dengan pendapat Slameto (1995) yaitu tingginya minat dalam 
suatu hal menjadi modal yang dapat dipergunakan dalam pencapaian/perolehan benda ataupun tujuan yang menjadi minat. Tingginya minat belajar cenderung berdampak pada tingginya prestasi seorang individu dan sebaliknya.

Permasalahan psikologis yang di alami oleh petani organik JARPETO diatasi dengan penerapan modal sosial dari para petani yaitu kepercayaan (trust). Hal ini dapat dilihat dari para subjek bahwa mereka tetap menggunakan sistem pertanian organik meskipun mendapatkan cibiran dan tekanan dari hubungan sosial. Seperti yang diungkapkan Setyarman

"ya itu kita praktikan bertani secara organik kita tunjukan pada para petani lain, kalau tementemen yang sudah pakai organik mereka langsung mempercayai ternyata hasilnya baik"

(Setyarman 47-50)

Modal sosial kepercayaan (trust) ini yang dipakai JARPETO untuk menghadapi permasalahan tekanan psikologis dari masyarakat. Selain modal sosial kepercayaan, untuk menjawab cibiran serta tekanan psikologis JARPETO juga memanfaatkan modal sosial berupa jaringan sosial (linking social capital) ke luar paguyuban. JARPETO memanfaatkan jaringan sosial keluar paguyuban dengan mengadakan sosialisasi serta demplot yang di adakan oleh PPL.

“...Akhirnya saya disuruh datang ke acara-acara kelompok tani saya disuruh memberikan materi tentang pertanian organik, nah ada petani yang usul kalau memang hasil dari pertanian organik bagus coba diadakan demplot. Saya jawab siap, akhirnya saya minta lahan untuk diadakan demplot dari salah satu petani, pada pelaksanaanya saya didampingi PPL"

(Setyarman 61-66)

Modal sosial kepercayaan (trust) yang digunakan petani JARPETO dalam menghadapi tekanan psikologis tersebut sependapat dengan Gede sadana (2013) bahwa kepercayaan adalah salah satu modal sosial yang melandasi para petani untuk melakukan kegiatan bersama dalam pelaksanaan kegiatan pertanian, sosial budaya, serta ekonomi. Gede sadana (2013) juga menjelaskan bahwa jaringan sosial yang dibentuk oleh petani dengan pihak luar bermanfaat dalam pembangunan pertanian.

Tabel 2. Modal Sosial dalam Mengatasi Masalah Psikologis

Permasalahan

Masalah Psikologis

a. Cibiran yang diterima dari petani lain

b. Asumsi negatif dari PPL selaku petugas dinas pertanian
Modal Sosial

a. Kepercayaan petani terhadap sistem pertanian organik : petani tetap konsisten melakukan pertanian organik meskipun mendapat cibiran.

b. Jaringan sosial : Menciptakan jaringan sosial ke luar paguyuban guna menjawab cibiran dan asumsi negatif terhadap sistem pertanian organik

\section{Efek Postif terhadap Kesehatan}

Masyarakat dunia mulai menyadari adanya bahaya yang diakibatkan oleh pemakaian bahan kimia sintesis dalam pertanian. Memasuki abad 21, masyarakat dunia mulai sadar bahaya yang ditimbulkan oleh pemakaian bahan kimia sintetis dalam pertanian. Orang semakin arif dalam memilih bahan pangan yang aman bagi kesehatan dan ramah lingkungan. Gaya hidup sehat dengan slogan "Back to Nature" telah menjadi trend baru meninggalkan pola hidup lama yang menggunakan bahan kimia non alami, seperti pupuk, pestisida kimia 
sintetis dan hormon tumbuh dalam produksi pertanian. Pangan yang sehat dan bergizi tinggi dapat diproduksi dengan metode baru yang dikenal dengan pertanian organik.

Menurut Inawati (2011), berkembangnya produsen dan komoditas organik ini karena pengaruh gaya hidup masyarakat sebagai konsumen yang mulai memperhatikan pentingnya kesehatan dan lingkungan hidup dengan menggunakan produk organik yang tidak menggunakan bahan-bahan kimia sintetis buatan. Setyarman selaku petani organik juga berpendapat bahwa dia mengartikan pertanian organik adalah sistem pertanian yang tidak menggunakan racun. Setyarman menambahkan bahwa penggunaan racun sangat berbahaya bagi kesehatan bahkan membunuh musuh alami yang bermanfaat bagi tanah, hal tersebut sependapat dengan Suwantoro (2008) menurutnya ada begitu banyak kehidupan di dalam tanah yang mati, yang berguna untuk menyuburkan tanah. Predator hama ikut mati sehingga ketergantungan terhadap pestisida semakin besar. Bahkan obat-obatan tersebut juga berbahaya bagi para pelaku pertanian.

Selain menghindari bahaya racun, manfaat pertanian organik adalah menghasilkan beras sehat. Kasno berpendapat bahwa dirinya dalam bertani organik mempunyai niat untuk bertani secara sehat, ramah lingkungan dan menghasilkan hasil pertanian yang sehat untuk dikonsumsi. Pernyataan Kasno tersebut sejalan dengan prinsip dasar bertani organik menurut Sihotang dalam Mayrowani (2012) yakni prinsip bertani organik dilakukan dengan "akrab" lingkungan serta memenuhi preferensi konsumen dan aman dikonsumsi.

Aspek kesehatan lain dari bertani yaitu menurut Sugiyo dan Rubadi mengkonsumsi hasil pertanian organik menghindarkan dari berbagai macam penyakit. Menurut mereka penyakitpenyakit pada masa sekarang ini diakibatkan oleh konsumsi makanan yang mengandung bahan kimia. Rubadi mencontohkan bahwa anak sekarang masih muda sudah menderita penyakit stroke, liver dan berbagai macam penyakit lainnya. Menurutnya berbagai macam penyakit tersebut timbul karena konsumsi makanan-makanan yang mengandung berbagai jenis bahan kimia. Pendapat Rubadi dan Sugiyo sama dengan pendapat Saragih (2003) menurutnya bahan kimia sintetis tersebut juga diyakini menjadi faktor utama yang mengakibatkan berkembangnya penyakit-penyakit yang mengganggu metabolisme seperti ginjal, lever, paru-paru dan sebagainya.

\section{Efek Positif terhadap Kondisi Ekonomi}

Pertanian organik di Indonesia masih sangat kurang diperhatikan oleh pemerintah, sebagian masyarakat telah sadar akan pentingnya mengkonsumsi makanan sehat. Pemikiran masyarakat mulai berkembang, aspek kesehatan sebagai pertimbangan dalam mengkonsumsi makanan meningkat. Hal tersebut menunjukkan bahwa pertanian sistem organik memiliki potensi yag sangat besar untuk dikembangkan pada masa mendatang. Efek ekonomi tak lepas dari efek yang ditimbulkan dari trend tersebut.

Setyarman, Kasno, Rubadi, Sugiyo mengalami efek positif secara ekonomi dari cara mereka menerapkan sistem pertanian organik. Mereka mengakui bahwa pengeluaran mereka berkurang setelah menerapkan sistem pertanian organik. Setyarman menjelaskan bahwa perbandingan harga kimia dan organik terpaut jauh apalagi harga obat kimia mahal-mahal, biayanya lebih murah organik apalagi kalau mau bikin pupuk sendiri. Sedangkan menurut Kasno biaya organik lebih rendah itu alasan Kasno masih tetap menggunakan sistem organik, Sugiyo dan Rubadi juga berpendapat hal yang sama yaitu pengeluaran organik lebih rendah dari kimia, apalagi kalau pupuk mengelola sendiri. Setyarman menambahkan pada saat dia berpindah dari kimia ke organik dia mengalami penyusutan biaya, pada saat menggunakan kimia dia mengeluarkan sekitar 6,5jt untuk mengelola 1 hektar lahan miliknya, pada saat berpindah ke organik pengeluaran dia hanya berkisar $5 \mathrm{jt}$. Perubahan biaya terletak pada pupuk dan obat-obatan untuk pengeluaran yang lain masih sama. 
Tabel 3. Analisis Perbandingan Biaya Organik dan Konvensional 1 Hektar

\begin{tabular}{|c|c|c|c|c|c|c|c|}
\hline \multirow[t]{2}{*}{ No } & \multirow{2}{*}{$\begin{array}{c}\text { Sumber } \\
\text { Pengeluara } \\
\mathbf{n}\end{array}$} & \multicolumn{3}{|c|}{ Organik } & \multicolumn{3}{|c|}{ Konvensional } \\
\hline & & $\begin{array}{c}\text { Jumlah } \\
\text { Kebutuha } \\
\text { n }\end{array}$ & $\begin{array}{l}\text { Harga } \\
\text { Satuan }\end{array}$ & $\begin{array}{l}\text { Jumlah } \\
\text { (Rp) }\end{array}$ & $\begin{array}{c}\text { Jumlah } \\
\text { Kebutuhan }\end{array}$ & $\begin{array}{l}\text { Harga } \\
\text { Satuan }\end{array}$ & $\begin{array}{c}\text { Jumlah } \\
\text { (Rp) }\end{array}$ \\
\hline 1 & Pupuk & 2 ton & 500.000 & 1.000 .000 & 7 kwintal & 200.000 & 1.400 .000 \\
\hline 2 & Benih & $25 \mathrm{~kg}$ & 4.000 & 125.000 & $25 \mathrm{~kg}$ & 4.000 & 125.000 \\
\hline 3 & Semprot & 10 liter & 30.000 & 300.000 & - & - & 500.000 \\
\hline 4 & Tanam & -- & - & 1.500 .000 & - & - & 1.300 .000 \\
\hline 5 & Traktor & - & 600.000 & 600.000 & - & - & 600.000 \\
\hline 6 & $\begin{array}{l}\text { Tenaga } \\
\text { (mopok,nyor } \\
\text { ok tamping } \\
\text { dsb) }\end{array}$ & - & 1.000 .000 & 1.000 .000 & - & - & 1.000 .000 \\
\hline 7 & Biaya Panen & - & - & 1.500 .000 & - & - & 1.500 .000 \\
\hline \multicolumn{2}{|c|}{ Jumlah Biaya } & - & - & 6.025 .000 & & & 6.425 .000 \\
\hline
\end{tabular}

Sedangkan menurut Rubadi perbedaan harga yang sangat mencolok dari obat kimia dan obat organik. Rubadi menggunakan obat organik seharga 20rb bisa untuk 3 kali semprot, sedangkan obat kimia harganya bisa mencapai ratusan ribu. Rendahnya biaya dalam pengelolaan sistem pertanian organik ini sependapat dengan penelitian yang dilakukan Nonik Karliya, Januarita, Siwi (2014) Sistem pertanian organik lebih hemat dalam biaya sarana produksi pertanian seperti pupuk dan pestisida dibandingkan sengan pertanian konvensional, sebab sebagian besar responden membuat sendiri pupuk dan pestisida alam yang mereka gunakan, sedangkan pupuk dan pestisida kimia yang digunakan di pertanian konvensional adalah hasil produksi industri yang harus dibeli. Sedangkan Widiarta (2011) menurutnya bahwa biaya yang dibutuhkan petani organik lebih tinggi dari petani konvensional.

\section{Efek Positif terhadap Pertanian}

Bertani organik tak lepas dari dampak terhadap tanah, tanaman, maupun hal lain yang dialami oleh petani. Petani organik JARPETO merasakan efek poitif dari cara bertani organik terhadap kondisi pertaniannya baik itu terkait lahan maupun tanamannya. Setyarman selaku petani organik merasakan perubahan pada tanamannya hasil pertanian yang dihasilkan dari pertanian organik dirasakan setyarman lebih baik. Sedangkan menurut kasno mengartikan hal yang sama mengenai pertanian organik yaitu pertanian organik membawa dampak positif terhadap kondisi pertaniannya. Kasno menganggap bahwa setelah berpindah ke bertani organik kondisi tanah yang dia kelola berubah, menurut Kasno tanah yang dikelola jadi lebih gembur, bakteri dalam tanah seperti cacing jadi lebih banyak. Sugiyo juga merasakan dampak positif terhadap tanahnya Sugiyo yang sudah lama bertani organik merasakan bahwa tanah yang dia kelola lebih gembur dan mudah dikelola karena hewan-hewan pengurai tanah seperti cacing hidup di tanah yang dikelola secara organik.

Berdasarkan pengalaman Rubadi, Rubadi juga merasakan efek positif terhadap kondisi tanahnya yaitu tanah menjadi lebih subur dan gembur berbeda dengan kimia kondisi tanahnya 
keras. Pendapat Kasno, Sugiyo dan Rubadi terkait efek positif penggunaan sistem pertanian organik sejalan dengan teori tanah bahwa Arsyad (2006) bahwa bahan organik dapat memegang air dua sampai empat kali bobotnya, oleh karena itu, tanah yang mengandung bahan organik tinggi juga memiliki kadar lengas yang tinggi. Sedangkan berdasarkan teori biologi pupuk organik yang kaya nutrien dan bermanfaat sebagai penyubur tanah. Prosesnya merupakan hasil perombakan senyawa komplek menjadi senyawa sederhana dengan bantuan kombinasi mikroba yang terdiri dari bakteri, kapang, aktinomisetes dan cacing yang dapat meningkatkan nilai limbah lignoselulosa (Mtui, 2009; Abdulla, 2007).

Selain membawa efek positif terhadap tanah sistem pertanian organik juga membawa efek positif terhadap tanamannya. Kasno dan Sugiyo berpendapat bahwa tanaman yang dihasilkan dari sistem pertanian organik memiliki karakteristik batang yang lebih kuat. Berdasarkan penuturan Sugiyo tanaman yang dihasilkan dari cara bertani organik lebih kuat atau dalam istilah jawa "Anteng" (tidak berubah-ubah/tetap). Pendapat Kasno dan Sugiyo sependapat dengan Ayub (2010) bahwa menurutnya tanaman yang di kelola menggunakan pupuk organik memiliki batang yang lebih kuat, kandungan mineral dan asam amino dalam pupuk organik mampu memepercepat pertumbuhan tanaman dan akar.

Rubadi dan Sugiyo berpendapat bahwa tanaman organik lebih tahan terhadap musim kemarau maupun musim hujan. Pada musim kemarau tanaman organik lebih tahan karena tanaman organik tahan terhadap penggunaan air yang sedikit. Pada musim penghujan tanaman organik juga lebih tahan karena batang yang lebih kuat sehingga tidak ambruk ketika diterpa angin atau hujan lebat.

Sugiyo menambahkan bahwa tanaman organik berbeda dengan tanaman kimia, menurutnya kalau kimia tumbuh subur hanya 2 bulan, tetapi kalau organik mampu tumbuh subur dalam waktu yang lama. Bahkan Sugiyo menambahkan bahwa tanaman organik batangnya kuat serta hijau sampai tanaman tua. Faktor lain selain tanamannya yaitu beras yang dihasilkan. Rubadi juga berpendapat hal yang sama yaitu tanaman organik memiliki karakteristik hijau nya lebih lama, kalau kimi menurut Rubadi cepat hijau tetapi tidak tahan lama seperti organik. Pupuk kandang padat (makro) akan memiliki banyak kandungan unsur fosfor $(\mathrm{P})$, nitrogen $(\mathrm{N})$, dan kalium $(\mathrm{K})$ sedangkan untuk kandungan unsur hara mikro yang ada dalam pupuk kandang diantaranya kalsium, magnesium, belerang, natrium, besi dan tembaga (Pranata, 2004).

Nitrogen $(\mathrm{N})$, yang berfungsi merangsang pertumbuhan tanaman secara keseluruhan, untuk sintesa asam amino dan protein dalam tanaman. Merangsang pertumbuhan vegetatif (warna hijau daun, panjang daun, lebar daun) dan pertumbuhan vegetatif batang (tinggi dan ukuran batang). Phospat (P) berfungsi untuk pengangkutan energi hasil metabolisme dalam tanaman, merangsang pembungaan dan pembuahan, merangsang pertumbuhan akar, merangsang pembentukan biji, merangsang pembelahan sel tanaman dan memperbesar jaringan sel. Kalium (K) berfungsi dalam proses fotosintesa, pengangkutan hasil asimilasi, enzim dan mineral termasuk air.

Berdasarkan penuturan Kasno beras yang dihasilkan dari bertani organik memiliki rasa yang lebih enak, menurut Kasno hal yang sama dirasakan anaknya yang mengkonsumsi beras organik dari hasil panennya. Sugiyo dan Rubadi juga menuturkan hal yang sama yaitu nasi dari beras organik memiliki rasa yang lebih enak, selain rasa enak nasi dari beras organik tahan lama dan tidak mudah basi.

Rubadi dan Kasno berpendapat bahwa selain pupuk organik yang memberikan efek positif obat organik juga memiliki keunggulan yaitu efektif dalam mengusir hama. Kasno menceritakan pengalamanya terkait masalah hama, pada waktu lahan pertanian di daerahnya diserang hama hasil pertanian miliknya masih mendapatkan hasil pertanian yang bagus. Padahal disisi lain petani lain yang menggunakan sistem pertanian kimia merasakan bahwa hasil dari pertaniannya anjlok bahkan gagal panen karena tanamannya tidak ada isinya. Dari 
penuturan kasno sistem pertanian organik dapat dijadikan sebagai solusi gagal panen yang disebabkan oleh hama. Rubadi menceritakan dulu ada hama walangsangit para petani kimia mengalami gagal panen karena gabah hasil nya kopog (tidak ada isinya) sedangkan yang pakai obat organik tidak mengalami hal tersebut. Rubadi juga menuturkan kalau obat organik itu lebih efektif mengusir hama, bahkan sampai tiga bulan setelah disemprot hama tidak akan kembali lagi.

\section{Bertani Organik karena Faktor Religius}

Pertanian organik memiliki banyak arti bagi setiap orang, setiap orang mengartikan pertanian organik bermacam-macam. Ada satu hal yang unik dan sangat luar biasa, seorang petani bernama Setyarman mengartikan pertanian organik dari segi nilai religius meskipun faktor ini hanya muncul di satu subjek tetapi faktor religius ini menjadi hal yang sangat menarik untuk dibahas.

Setyarman selaku petani organik sekaligus Ketua JARPETO kabupaten Sukoharjo beranggapan bahwa setiap kehidupan manusia itu sudah diatur dalam ayat suci Al Quran, termasuk dalam hal bertani. Pernyataan Setyarman tersebut sependapat dengan Nasution (1992) dalam al-Qur'an dijelaskan bahwa manusia diciptakan sebagai khalifah di bumi. Kewajiban manusia terkait perannya adalah menjaga dan mengurus bumi serta segala hal yang ada di dalamnya untuk dikelola sebagaimana mestinya. Kekhalifahan sebagai tugas dari Allah untuk mengurus bumi harus dijalankan sesuai dengan kehendak pencipta-Nya dan tujuan pencipta-Nya.

Setyarman beranggapan bahwa bertani tidak bisa seenaknya sendiri, karena menurutnya kalau seenaknya sendiri bisa saja terjerumus ke cara-cara yang bertentangan dengan yang Tuhan atur dalam kitab suci-Nya. Temasuk didalamnya Tuhan melarang manusia untuk merusak tanah. Pendapat Setyarman tersebut sesuai dengan Ulama Fiqh Yusuf al-Qardhawi dalam Ri'âyatu al-Bi'ah fi al-Syarî'ati al-Islâmiyyah menjelaskan mengenai posisi pemeliharaan ekologis (hifdz al-`âlam) dalam Islam yaitu pemeliharaan lingkungan setara dengan menjaga maqâshidus syarî'ah (memlihara agama, memelihara akal, memelihara jiwa, memelihara harta benda, memelihara keturunan) (Hakam, 2002).

Setyarman selalu mengajak petani yang lain untuk bertani sesuai aturan Tuhan. Setyarman menganggap kalau kita bertani sesuai dengan aturan maka tanah akan subur sesuai dengan ijin Allah hasil pertanian pun akan meningkat pendapatan otomtis akan meningkat. Menurut Setyarman bertani organik itu tidak hanya berorientasi tentang kesehatan dan lingkungan tapi lebih dari itu yaitu bertani organik hakekatnya bertani menjalankan perintah Allah.

Setyarman menjelaskan bahwa keuntungan paling mendasar dalam dia bertani orgaik yaitu kepuasan secara batin, setelah batin merasa puas Setyarman mengakui mendapatkan ketenangan batin karena bertani sesuai yang dianjurkan oleh Allah. Setyarman beralasan dengan mengajak petani lain untuk bertani organik dia mengharapkan mendapat keberkahan dalam hidupnya dikarenakan Allah mengajarkan manusia untuk mengkonsumsi makanan yang halalan tayiban.

Kelompok tani JARPETO menggunakan modal sosial berupa nilai dalam menjalankan sistem pertanian organik. Nilai dan Norma dalam kelompok tani JARPETO yaitu berupa nilai religius, Modal sosial ditransmisikan melalui mekanisme-mekanisme kultural seperti agama, tradisi, atau kebiasaan sejarah(Fukuyama, 2001). Nilai ini berperan untuk mendorong petani untuk bertani secara organik yakni menekankan bahwa pertanian organik sesuai dengan aturan Tuhan dan menghindari dosa yang akan ditanggung dikemudian hari.

"Makanya dalam bertani organik ini tidak hanya berorientasi tentang kesehatan, tentang lingkungan, pada hakekatnya kita bertani organik yaitu bertani sesuai aturan Tuhan" (Setyarman 136-141). 
Pernyataan Setyarman tersebut berarti dalam kelompok tani JARPETO terdapat norma agama yang mesti dijalankan. Sudarmi dan Indriyanto (2009) mengartikan bahwa norma agama adalah seperangkat aturan yang mutlak karena diciptakan oleh Tuhan.

Kelompok tani JARPETO memanfaatkan jaringan sosial (linking social capital) sebagai media sosialisai mengenai aspek nilai dan norma dalam bertani.

"Setiap pertemuan-pertemuan pelatihan saya selalu menurunkan ayat-ayat al- Quran, karena dalam hidup kita harus mempunyai pedoman" (Setyarman 134-135).

Setyarman selalu memberikan siraman rohani pada saat memberikan materi tentang pertanian organic di setiap pelaksanaan pertemuan JARPETO.

\section{SIMPULAN}

Pertanian organik JARPETO mampu bertahan dan berjalan dengan baik dalam pelaksanaan pertanian organik. Berdasarkan hasil analisis eksplorasi pengalaman petani dalam menerapkan sistem pertanian organik dijelaskan bahwa :

1. Petani organik mengartikan sistem pertanian organik menjadi enam arti yaitu :

a. Memberikan pandangan dan pengalaman dalam bertani

b. Efek psikologis dari bertani organik

c. Bertani karena faktor psikologis

d. Efek positif terhadap kondisi ekonomi

e. Efek positif terhadap kesehatan

f. Bertani organik memberikan efek positif terhadap kondisi pertanian

2. Kelompok tani JARPETO menggunakan modal sosial :
a. Nilai : Nilai Agama, Nilai Moral (kebaikan)
b. Norma : Norma Religius
c. Kepercayaan : Percaya terhadap pertanian organik.
d. Jaringan sosial : Jaringan sosial ke dalam dan jaringan sosial keluar

3. Pembangunan pertanian organik diharapkan mendorong pembangunan dalam tiga aspek penting.

a. Ekonomi : diharapkan dengan hadirnya sistem pertanian organik mampu menaikkan pendapatan petani serta tingkat kesejahteraan.

b. Kesehatan : diharapkan dengan hadirnya sistem pertanian organik mampu meningkatkan kesehatan baik petani maupun konsumen.

c. Ekologi : dalam hal ini diharapkan dengan hadirnya sistem pertanian organik mampu meningkatkan kualitas tanah, kualitas air, kualitas tanaman dan meningkatkan keanekaragaman hayati.

\section{DAFTAR PUSTAKA}

Anonim, 2011. Pengaruh Perubahan Sosial dan Dampaknya. (http://id.shvoong. com/socialsciences/sociologi/2157404/pengaruh-perubahan-sosial-dan-dampaknya). Diakses 28 Maret 2017.

Arsyad S. 2006. Konservasi Tanah dan Air. Edisi Kedua Cetakan Pertama., Penerbit IPB Press, Bogor.

AOI. 2011. Produsen dan Produk Organik Bersertifikat Meningkat. Bogor. http://www.organicindonesia.org/05infodata -news.php?id=221. Diakses 20 Juli 2016.

Fukuyama, F. (2001). Social Capital, Civil Society, and Development. Third Word Quarterly, $22(1), 7-200$.

Hadisapoetro, Soedarsono. 1975. Pembangunan Pertanian. Yogyakarta : UGM.

Herdiansyah, Haris. 2009. "Metode Penelitian Kualitatif untuk Ilmu Sosial”. Jakarta: Salemba Humanika. 
Inawati, L. 2011. Manajer Mutu dan Akses Pasar Aliansi Organis Indonesia (AOI), semiloka "Memajukan Pertanian Organis di Indonesia: Peluang dan Tantangan kedepan". Yayasan Bina Sarana Bhakti di Cisarua, Bogor, Jawa Barat (14/3/2011).

Mtui, Y.S. 2009. Recent Advances in Preatreatment of Lignocellulosic Wastes and Production of Value Added Products

Mayrowani, Henny. 2012. "The Development of Organic Agriculture in Indonesia". Jurnal Forum Penelitian Agro Ekonomi, Volume 30 No. 2, Desember 2012 : 91 - 108.

Nasution, Harun. 1992. "Ensiklopedi Islam Indonesia". Jakarta : Djambatan.

Noknik K, Januarti H, Siwi N. 2014. Viabilitas Pertanian Organik Dibandingkan Pertanian Konvesional. Laporan Akhir Penelitian. Perjanjian No : III/LPPM/2014-3/48-P. Universitas Katolik Parahyangan.

Oudejans, Jan H.M. Oudejans. 2006. Perkembangan Pertanian di Indonesia. Yogyakarta : Gadjah Mada University Press.

Pranata,Ayub S., 2010. Meningkatkan Hasil Panen dengan Pupuk Organik. Jakarta : PT Agromedia Pustaka.

Prawoto, A. and Surono I. 2005. Organic Agriculture in Indonesia : A Wannabe Big Player in the Organic World, http://eng.biocert.or.id/. Diakses pada 03 Januari 2017.

Putnam, R.D. 1996. "Who Killed Civic America?". Prospect. Vol 7. No. 24. pp. 66-72.

Qardhawi, Yusuf al-, Islam Agama Ramah Lingkungan. Abdullah Hakam Shah, dkk. (terj.)., Jakarta: Pustaka Al-Kautsar, 2002.

Roidah, Ida Syamsu. 2013. "Manfaat penggunaan Pupuk Organik Untuk Kesuburan Tanah". Jurnal Universitas Tulungagung BONOROWO. Vol.1 , No.1 Tahun 2013.

Saragih, Sebastian. 2003. "Kemerdekaan Petani dan Keberlanjutan Kehidupan". Yogyakarta : STPN HPS.

Sedana, Gede. 2013.’Modal Sosial Dalam Pengembangan Agribisnis Petani pada Sistem Subak di Bali". Disertasi. Dipublikasikan, Fakultas Pertanian Universitas Udayana.

Slameto . 1995. Belajar dan Faktor-Faktor Yang Mempengaruhi. Label 370,1523 SLA b. Rineka Cipta. Jakarta

Smith, J.A., Flowers, P., Larkin, M. (2009), Interpretative Phenomenological analysis-theory, method, and research. London : Sage Publications.

Sudarmi, Sri. W. Indriyanto. 2009. Sosiologi Untuk Kelas X SMA dan MA. Jakarta: Pusat Perbukuan Departemen Pendidikan Nasional.

Sutanto, Rachman. 2002. Penerapan Pertanian Organik. Permasyarakatan dan Pengembangannya. Yogyakarta : Penerbit Kanisius.

Suwantoro. 2008. Analisis Pengembangan Pertanian Organik di Kabupaten Magelang (Studi Kasus Desa Sawangan). Tesis . Program Magister Ilmu Lingkungan. Universitas Diponegoro.

Widiarta .2011. “Analisis Keberlanjutan Praktik Pertanian Organik di Kalangan Petani”. Jurnal Sosiologi Pedesaan, Vol. 5, No. 1 pp 71-89.

Yanti, R. 2005. "Aplikasi Tekhnologi Pertanian Organik: Penerapan Pertanian Organik oleh Petani Padi Sawah Desa Sukorejo Kabupaten Sragen. Tesis. Universitas Indonesia. 